\title{
O ENSINO DE MATEMÁTICA PARA CEGOS NO MUNICÍPIO DO RIO
}

\section{GRANDE}

\section{MATHEMATICS TEACHING TO THE BLIND IN RIO GRANDE, RS, BRAZIL}

\author{
Daner Silva Martins ${ }^{1}$ \\ Maria do Carmo Galiazzi ${ }^{2}$ \\ Cleiva Aguiar de Lima ${ }^{3}$
}

\begin{abstract}
Resumo: Este trabalho apresenta uma análise acerca da experiência escolar de cegos da cidade do Rio Grande que alcançaram o nível universitário em relação à aprendizagem de Matemática, com o objetivo de compreender como ocorreu o ensino de Matemática, a fim de orientar os processos de formação de professores e, com isto, contribuir para o ensino de Matemática para pessoas cegas. Foram realizadas entrevistas narrativas com estes alunos, no intuito de escutar suas histórias sobre os processos de ensino e aprendizagem de Matemática. A fim de analisar os elementos emergentes destas falas, utilizei a Análise Textual Discursiva. O reconhecimento do outro, a perspectiva dos cegos sobre o sistema educacional e as dificuldades enfrentadas neste percurso escolar foram destados nas falas dos entrevistados. O diálogo surge como categoria emergente das entrevistas, enquanto a experiência estética é apontada como potencial para a abertura à alteridade, em um viés ético da filosofia da educação.
\end{abstract}

Palavras-chave: Ensino de Matemática para Cegos; Formação de Professores de Matemática; Educação Matemática Inclusiva; Materiais Didáticos.

\begin{abstract}
This study analyses blind college students' experience regarding Mathematics in Rio Grande, RS, Brazil. It aims at outlining how Mathematics teaching occurred in order to guide teacher education processes and, thus, contribute to Mathematics teaching to the blind. Narrative interviews were conducted with the students so as to listen to their stories about Mathematics teaching and learning processes. The Discursive Textual Analysis was used to analyse elements that arose from their narratives. Recognition of the other, views of the educational system and difficulties faced by the blind in their journeys were some issues they mentioned. Dialogue appeared as an emergent category in the interviews while the aesthetic experience was considered the potential that enables opening to otherness, in an ethical view of Education Philosophy.
\end{abstract}

Keywords: Teaching Mathematics to the Blind; Mathematics Teacher Education; Inclusive Mathematics Education. Teaching Materials.

\footnotetext{
${ }^{1}$ Doutor em Educação em Ciências: Química da vida e Saúde da Universidade Federal do Rio Grande (FURG). Professor do Instituto Federal do Rio Grande do Sul (IFRS) - Campus Rio Grande, Rio Grande, Rio Grande do Sul, Brasil. E-mail: daner.martins@ riogrande.ifrs.edu.br

${ }^{2}$ Doutora em Educação pela Pontifícia Universidade Católica do Rio Grande do Sul (PUC). Professora da Universidade Federal do Rio Grande (FURG), Rio Grande, Rio Grande do Sul, Brasil. Email: mcgaliazzi@gmail.com

${ }^{3}$ Doutora em Educação Ambiental pela Universidade Federal do Rio Grande (FURG). Professora do Instituto Federal do Rio Grande do Sul (IFRS) - Campus Rio Grande, Rio Grande, Rio Grande do Sul, Brasil. Email: cleiva.lima@ riogrande.ifrs.edu.br
} 


\section{Introdução}

Este artigo apresenta uma compreensão sobre a experiência escolar em relação à disciplina de Matemática de seis alunos cegos, a partir da escuta das narrativas de suas vivências nos processos de ensino e aprendizagem de Matemática. Os entrevistados concluíram o Ensino Médio na cidade do Rio Grande (RS) e atualmente são acadêmicos ou egressos de duas instituições de ensino superior da referida cidade.

A análise dessas narrativas possibilitou compreender os processos de ensino e aprendizagem da referida disciplina para estes sujeitos. Além disso, este artigo aponta para situações de sucesso escolar de alunos cegos que podem vir a inspirar ações, sobretudo de formação, que venham ao encontro das demandas dos cegos em seu processo de escolarização.

Para isso, foram realizadas entrevistas com esses seis alunos, no intuito de escutar suas vivências escolares e, principalmente, sua relação com a Matemática e com os professores desta disciplina, ao longo da Educação Básica. A questão orientadora do estudo foi: o que é isso: a aprendizagem de Matemática a partir da experiência de alunos e professores cegos?

Inicialmente, traço um panorama acerca dos números referentes aos níveis de escolarização dos deficientes no Brasil. A seguir, situo a educação de deficientes visuais na cidade do Rio Grande, especialmente, a partir da Escola de Educação Especial José Alvares de Azevedo. Em momento posterior, discorro acerca dos procedimentos para produção dos dados da pesquisa, as entrevistas com os estudantes cegos. Na sequência, descrevo as etapas realizadas para análise dos dados a partir da Análise Textual Discursiva (ATD): a unitarização, a categorização e produção do metatexto.

A partir da análise das informações discursivas, classifiquei as unidades de significados em três categorias emergentes: Alguém notou a presença do outro - Abertura à alteridade, A visão do cego sobre a cegueira e A cegueira de quem não enxerga a alteridade. Debrucei-me na literatura que embasou a análise destas três categorias e, a partir, principalmente, dos estudos da Filosofia da Educação, construí o metatexto. Neles, o diálogo emergiu como componente fundamental para o reconhecimento da alteridade.

Para finalizar, apresento as considerações finais, em que sinalizo para a introdução da experiência estética na formação de professores de Matemática como horizonte que possibilita a abertura à alteridade. Ao longo do texto, recorro a artefatos estéticos em que a cegueira é protagonista (poemas, vídeos, filmes, livros e charges), elementos estes os 
quais dispõem do potencial de sensibilizar a comunidade escolar para as demandas do aluno cego, de modo que esta possa abrir-se à alteridade.

\section{Contexto da pesquisa}

As informações disponíveis na Cartilha do Censo 2010 da pessoa com deficiência apontam que, entre a população brasileira, há $23,90 \%$ de pessoas com algum tipo de deficiência. A que aparece com maior incidência é a visual, com 18,60\%, seguida da motora $7 \%$, a auditiva $5,10 \%$ e, finalmente, a mental ou intelectual, com 1,40\%.

Apesar dos inegáveis avanços das últimas décadas no que se refere ao acesso das pessoas com deficiência ao ensino regular - principalmente após o apelo político em prol da inclusão, desde a Declaração de Salamanca ${ }^{4}(1994)$ - ainda é preciso avançar, pois os deficientes estão à margem do sistema escolar.

$\mathrm{Na}$ cartilha do censo (2010) da pessoa com deficiência consta que $61,1 \%$ da população com deficiência não possui instrução ou têm o ensino fundamental incompleto, enquanto a população sem nenhuma deficiência representa 38,2\% para o mesmo nível de instrução. Com relação aos alunos de graduação, ênfase deste ensaio, cabe destacar que apenas $6,7 \%$ das pessoas com deficiência concluem esta etapa da escolarização.

\section{Educação de cegos na cidade do Rio Grande}

Em 1962, foi fundada em Rio Grande, por iniciativa do Rotary Club, uma sociedade civil de amparo aos cegos, chamada Escola de Educação Especial José Alvares de Azevedo. Esta é mantida por doações da comunidade e grande parte de seu quadro docente é cedido pela Prefeitura Municipal do Rio Grande. A instituição tem por finalidade promover a habilitação ou reabilitação da pessoa com deficiência visual na sociedade.

A escola oferece Educação Infantil (psicopedagogia inicial e pré-escolar; Ensino Fundamental - anos iniciais), além do ensino da simbologia Braille para jovens e adultos. Ademais, a referida instituição conta com uma sala de recursos multifuncionais, onde são atendidos os alunos da rede regular de ensino, principalmente aqueles que não possuem

\footnotetext{
${ }^{4}$ Considerada como o marco mundial da educação inclusiva, a Declaração de Salamanca foi realizada em 1994, sob a organização do governo Espanhol e a Organização das Nações Unidas para a Educação, a Ciência e a Cultura (UNESCO), a Conferência Mundial sobre Necessidades Educativas Especiais: acesso e qualidade. Participaram do encontro representantes de 92 países e de 25 organizações internacionais, com a finalidade de promover a Educação para todos.
} 
a referida sala em sua escola de origem, com o atendimento educacional especializado (AEE).

\section{Metodologia da pesquisa}

Para mapear os alunos cegos da rede pública que haviam frequentado ou estavam cursando o ensino superior na cidade do Rio Grande, realizei uma consulta na pró-reitoria de Assuntos Estudantis da Universidade Federal do Rio Grande (FURG). Para obter tais dados na rede particular de nível superior presencial, contatei a Faculdade para aferir o número de estudantes cegos que haviam frequentado a instituição. Na sequência, foi realizado o primeiro contato com os participantes, por telefone ou e-mail, a fim de apresentar a proposta e efetuar o convite para participação na pesquisa.

Cabe destacar que a relação de estudantes fornecida pela FURG não distinguia os $\operatorname{cegos}^{5}$ dos com baixa visão ou ainda dos alunos com visão monocular. Dos vinte e seis estudantes relacionados pela instituição, nos contatos telefônicos e por e-mail, aferi que apenas quatro são cegos. Destes, três já haviam concluído o ensino superior e um é acadêmico da graduação. Da faculdade particular, foram mapeados três alunos cegos, dos quais dois foram entrevistados e um não consegui contato.

Um aspecto o qual merece destaque diz respeito ao fato de que, apesar de a FURG ter quase 50 anos de história, os cegos não tiveram acesso a ela, a exceção de um caso, apenas a partir de 2010. Este caso se refere a uma ex-professora cega (in memoriam) a qual se formou em Licenciatura em Pedagogia-Licenciatura plena, em 1979. Isso significa que houve um hiato de 40 anos para que os cegos da cidade do Rio Grande voltassem a exercer seu direito de acesso ao ensino superior.

Após a concordância dos participantes da pesquisa, as entrevistas foram realizadas entre os meses de janeiro e maio de 2017. O entrevistado escolhia, de acordo com sua disponibilidade, o local, a maneira (presencial ou Skype), a data e o horário para a conversa. As entrevistas foram gravadas em áudio e vídeo, quatro presenciais e duas por Skype, com o consentimento livre e esclarecido dos participantes.

${ }^{5}$ De acordo com o Professor Antônio João Menescal Conde, do Instituto Benjamin Constant, "Pedagogicamente, define-se como cego aquele que, mesmo possuindo visão subnormal, necessita de instrução em Braille (sistema de escrita por pontos em relevo) e como portador de visão subnormal aquele que lê tipos impressos ampliados ou com o auxílio de potentes recursos ópticos" (CONDE, 2016, p.2). 
Compõem o corpus $^{6}$ as entrevistas: da pedagoga Luize, 30 anos, formada pela FURG, em 2013 e professora municipal; da advogada Lediane, 29 anos, formada pela FURG, em 2015; da pedagoga Josiane, 34 anos, formada pela FURG, em 2016 e com pós-graduação em educação especial; do acadêmico Marcelo ${ }^{7}, 35$ anos, do $6^{\circ}$ semestre do curso de Geografia-Licenciatura, da FURG; do acadêmico Fábio, 23 anos, do $10^{\circ}$ semestre do curso de Direito, da Universidade Particular; e da acadêmica Suelen, 30 anos, do $3^{\circ}$ semestre do curso de Psicologia, da Universidade Particular.

Para a obtenção do corpus, foi utilizada a pesquisa narrativa, metodologia a qual, segundo Clandinin e Connelly (2011), corresponde ao “[...] melhor modo de representar e entender a experiência. Experiência é o que estudamos, e estudamos a experiência de forma narrativa porque o pensamento narrativo é uma forma-chave de experiência e um modo-chave de escrever e pensar sobre ela" (CLANDININ; CONNELLY, 2011, p.48).

A cada participante foi solicitado que narrasse suas experiências escolares em que a Matemática estivesse presente. Neste sentido, a intenção foi ouvir, atentamente, o que os alunos tinham a dizer, sobretudo em relação aos fatos significativos que acercam o ensino e a aprendizagem da Matemática durante o percurso na Educação Básica.

Após escuta e transcrição das entrevistas, foi iniciado o processo de análise. Para tanto, utilizei a Análise Textual Discursiva (ATD), proposta por Moraes e Galiazzi, a qual pode ser entendida

[...] como o processo de desconstrução, seguido de reconstrução, de um conjunto de materiais linguísticos e discursivos, produzindo-se a partir disso novos entendimentos sobre os fenômenos e discursos investigados. Envolve identificar e isolar enunciados dos materiais submetidos à análise, categorizar esses enunciados e produzir textos, integrando nestes descrição e interpretação, utilizando como base de sua construção o sistema de categorias construídos (MORAES; GALIAZZI, 2013, p. 112).

O primeiro movimento da ATD corresponde à desconstrução do material linguístico e denomina-se de unitarização. Este é descrito pelos autores da metodologia da seguinte forma: “[...] unitarizar um texto é desmembrá-lo em unidades elementares, correspondendo a elementos discriminantes de sentidos, significados importantes para a finalidade da pesquisa, denominadas de unidades de sentido ou de significado" (MORAES; GALIAZZI, 2013, p. 49).

\footnotetext{
${ }^{6}$ Todos os entrevistados assinaram termo de consentimento livre e esclarecido, no qual declaram estar cientes da finalidade das entrevistas.

${ }^{7}$ Marcelo foi o primeiro cego a ingressar no curso de Matemática Licenciatura Plena na FURG. Entretanto, este acabou evadindo em virtude da dificuldade com a resolução de exercícios em Braille, conforme declarou em entrevista: "Imagina fazer um limite ou uma derivada em Braille, enquanto meus colegas gastavam uma folha para resolver eu gastava três ou quatro, quando eu errava no meio, socorro!” (M. 29).
} 
Inicialmente, foi realizada uma leitura atenta e pormenorizada de cada uma das seis entrevistas e, a partir dos diferentes significados, estas foram desmembradas em unidades de significado, em um total de 273. Segundo Moraes e Galiazzi (2013), a unitarização é o momento em que o autor da pesquisa busca, após a leitura atenta do material, atribuir compreensões para o material linguístico a partir da determinação das unidades de sentido ou significado. Assim, novas interpretações sobre o corpus emergem, possibilitando o direcionamento dos rumos da investigação.

Para o agrupamento destas unidades, criei um arquivo no software Microsoft Excel 2016, em que às falas de cada entrevistado foi atribuída uma cor e a cada unidade da análise, um código, de acordo com a autoria e o número da unidade.

De acordo com Moraes e Galiazzi (2013), “a ATD constitui-se em um processo em espiral. Nisto se inclui a unitarização, também de caráter cíclico, de retomada periódica dos mesmos elementos, em um contínuo refinamento" (p. 71). Este movimento cíclico visou facilitar o processo recursivo proposto pela ATD, uma vez que, a partir desta codificação, foi possível a criação de links que remetiam ao corpus original, o que me permitia recuperar o contexto em que foi enunciada a unidade correspondente.

Figura 1: Desconstrução e unitarização das entrevistas

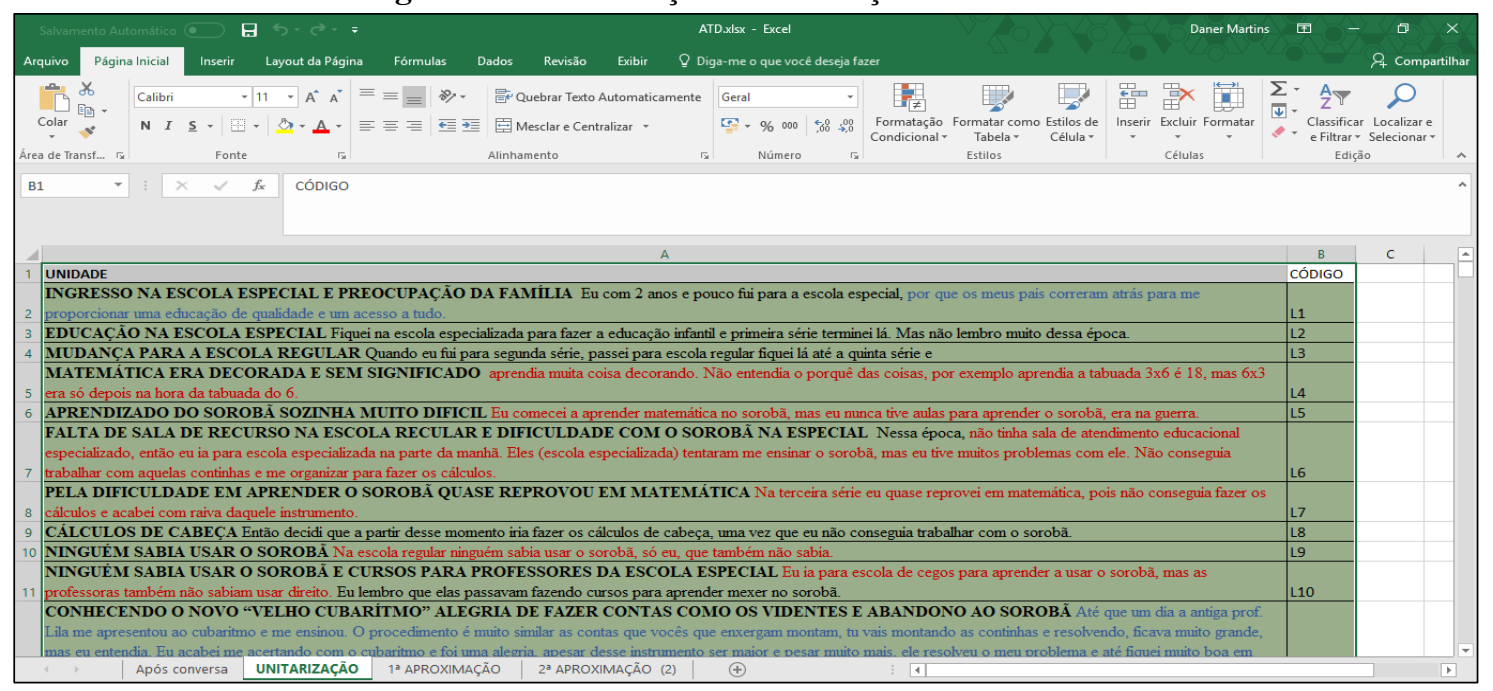

Fonte: Construção do autor (2020)

A seguir, atribuí um título para cada uma das unidades. Para isso, procurei atentar para as palavras-chave utilizadas pelo entrevistado em sua explanação. Este processo demanda que o pesquisador preste atenção aos detalhes, no intuito de fazer emergir novas interpretações. A partir deste olhar minucioso, é possível que o pesquisador se aproprie profundamente do corpus, o que pode facilitar a próxima etapa da ATD, a categorização. 
O segundo momento da ATD, o de categorização, de acordo com Moraes e Galiazzi (2013, p.75), “corresponde a simplificações, reduções e sínteses de informações da pesquisa, concretizadas por comparação e diferenciação de elementos unitários, resultando em formação de conjuntos de elementos que possuem algo em comum”.

Este processo consistiu na construção de uma nova aba com a primeira aproximação das unidades de significado no intuito de encontrar as categorias iniciais de análise. Após uma releitura atenta das unidades, aproximei as 273 unidades, em 44 categorias iniciais. Então, foi realizada nova categorização, sempre interligada por links para retornar às construções anteriores, com o objetivo de realizar a segunda aproximação, chamada de categorias intermediárias. Nessa etapa, obtive 11 categorias em que os aprendizes cegos discorreram sobre: escola especial; recursos e material adaptado; dificuldades com a Matemática; professor de Matemática; escola regular; apoio da família e outras pessoas; atendimento educacional especializado (AEE); relação professor/aluno; código de Matemática em Braille; informática na Matemática e dificuldade em concursos.

O processo de análise proposto pela ATD é recursivo e necessita de tempo para o pesquisador visualizar e maturar o que emerge dos seus dados de pesquisa, tal como Moraes e Galiazzi argumentam.

É preciso compreender, no entanto, que uma análise não pode restringir-se à aplicações de teorias do pesquisador. Este precisa exercitar um esforço de fidelidade às ideias dos sujeitos da pesquisa. É preciso atenção aos sentidos que os autores dos textos pretenderam expressar. Isso implica exercitar uma atitude de respeito ao outro, uma atitude fenomenológica de "deixar que o fenômeno se manifeste". Somente assim o pesquisador poderá avançar em suas compreensões teóricas (MORAES; GALIAZZI, 2013, p. 53).

Além disso, esta recursividade se manifesta também em momentos de interação com outros pesquisadores, o que pode ser fundamental no processo analítico. Exemplo disso se deu em uma apresentação a respeito das categorias intermediárias para o grupo de pesquisa, Comunidades Aprendentes em Educação Ambiental, Ciências e Matemática (CEAMECIM), ocasião em que foi sugerido maior atenção para aspectos de sucesso, bem como possibilidades para a abordagem da Matemática com este público.

Então, revisitei minhas observações e releituras, a partir das categorias intermediárias. Em uma nova categorização colocada em nova aba da tabela, percebi que os dizeres dos entrevistados agrupados nas onze categorias intermediárias versavam sempre sobre três aspectos: em todo relato de sucesso educacional, existe a presença de alguma pessoa, a qual notou a dificuldade do cego e o ajudou; como o cego gostaria que acontecesse sua educação na escola regular e a invisibilidade das dificuldades 
encontradas pelos cegos na escola regular. Sendo assim, concluí esta etapa com três categorias: Alguém notou a presença do outro - Abertura a alteridade, A "visão" do cego sobre a cegueira e A cegueira de quem não enxerga a alteridade. A partir da categorização, concentrei-me na intensificação de interlocução teórica para subsidiar a análise das falas dos entrevistados.

Finalmente, a última etapa da ATD, a de comunicação do novo, ocorre a partir da construção de um metatexto para cada uma das categorias, entrelaçando os dizeres dos entrevistados com a fundamentação teórica selecionada a partir das categorias de análise. De acordo com Moraes e Galiazzi,

[...] a análise textual discursiva pode ser caracterizada como exercício de produção de metatextos, a partir de um conjunto de textos. Nesse processo constroem-se estruturas de categorias, que ao serem transformadas em textos, encaminham descrições e interpretações capazes de apresentarem novos modos de compreender os fenômenos investigados (MORAES; GALIAZZI, 2013, p. 112).

$\mathrm{Na}$ sequência, apresento o metatexto resultante do entrelaçamento entre as contribuições teóricas às três categorias emergentes das narrativas dos alunos cegos de nível universitário da cidade do Rio Grande.

\section{Metatexto}

\section{1 alguém notou a presença do outro - abertura à alteridade}

Figura 2: Cartoon ilustrativo sobre a categoria

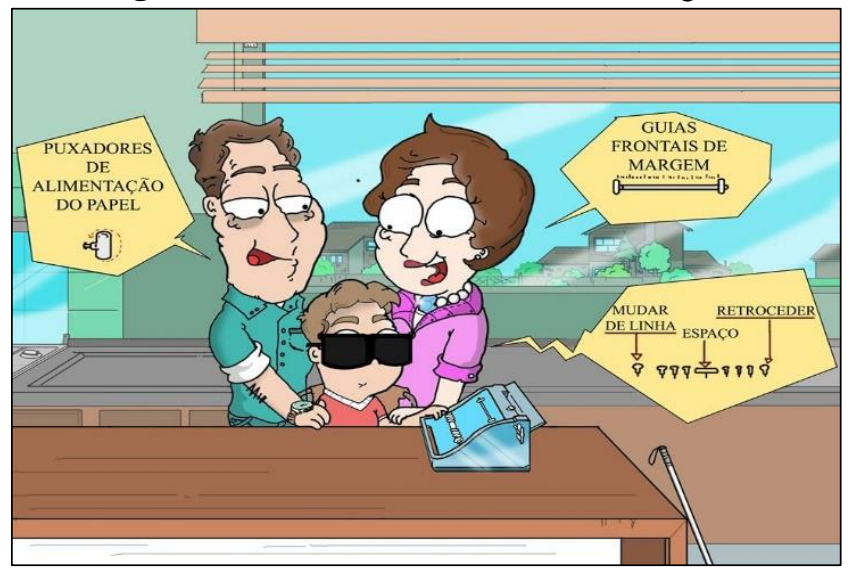

Fonte: Alisson Mendes (egresso do IFRS - campus Rio Grande) ${ }^{8}$

\footnotetext{
${ }^{8}$ Com o intuito de ilustrar esteticamente cada categoria deste ensaio, solicitei ao egresso do IFRS - Campus Rio Grande, Alisson Mendes a confecção de cartuns.
} 
Para iniciar a discussão acerca da presente categoria, recorri a definição da palavra 'alteridade' que, segundo o dicionário eletrônico Houaiss (2009), designa: "natureza ou condição do que é outro, do que é distinto, ou ainda situação, estado ou qualidade que se constitui através de relações de contraste, distinção, diferença”. De acordo com a Filósofa

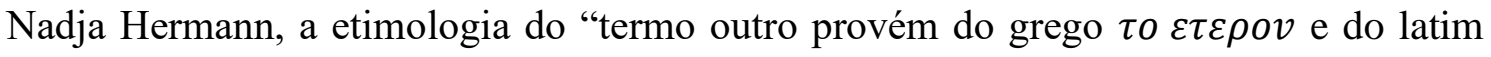
alteritas. Costuma ser empregado como equivalente a alteridade, que significa constituirse como outro" (HERMANN, 2017, p. 27).

Historicamente, a escola foi pensada e projetada a fim de atender a um padrão de normalidade instituído pela sociedade e aceito culturalmente. Neste contexto, o outro é o cego e, inicialmente, é necessário identificá-lo no âmbito educacional para vislumbrar suas peculiaridades. Para auxiliar nesta tarefa, trago uma reflexão referente a esta demarcação na instituição escolar, realizada pela filósofa da educação Nadja Hermann, segundo a qual:

[...] a educação tende a ver o outro como tudo o que se opõe às idealizações: o bárbaro, o selvagem, o infiel. Transpõe, tanto para o cotidiano como para o âmbito das especialidades científicas e também para o âmbito cultural, o peso interpretativo dessas oposições e identifica o educando como o desviado, o desadaptado, o desobediente, o hiperativo etc (HERMANN, 2014, p.479).

As situações que se afastam deste modelo pré-estabelecido pelo sistema escolar, o universal formal, são excluídas ou caem em esquecimento. Hermann ressalta que aqueles que por diversas razões não se adaptam são negligenciados e acabam por sofrer violência decorrente da falta de reconhecimento.

O universal formal, presente nas idealidades pedagógicas, define padrões de comportamentos, características e normas de ação para alunos que deixam escapar aquilo que não se enquadra nessa determinação. Frequentemente sofre preconceitos quem não aprende no mesmo ritmo, não demonstra certas habilidades específicas, como a habilidade lógico-Matemática, ou apresenta dificuldades na linguagem oral, porque o ideal, definido abstratamente, exige do aluno as características desde já pressupostas não só pelo professor, como também pela organização curricular e didático-pedagógica (HERMANN, 2014, p. 485).

De acordo com esse cenário, o aluno cego se enquadra perfeitamente em tal descrição, uma vez que a história da educação mostra a reincidência de casos de exclusão deste, no âmbito da escola. Ainda que se tenha assegurada, através dos sucessivos aperfeiçoamentos acerca da legislação educacional, desde a Declaração de Salamanca, a presença deste “outro" na sala de aula regular, a inclusão do aluno cego por vezes é parcial ou mesmo apenas simbólica. Isto porque, em muitos casos, não são consideradas as especificidades da cultura do cego, como o uso de materiais concretos e do sistema Braille, o que gera sua invisibilidade em sala de aula. 
Cabe ressaltar que até mesmo o oferecimento de AEE não garante necessariamente uma abertura à alteridade, pois, em alguns casos, há desconhecimento de Matemática ou do uso dos recursos disponíveis para o ensino da disciplina pelos profissionais que atuam neste setor, como vai ser apontado na análise das entrevistas.

Ainda de acordo com Hermann (2017), existem duas categorias provenientes da hermenêutica que contribuem de maneira significativa para uma abertura à alteridade: 0 diálogo e a experiência estética. Neste texto, optei por enfatizar a importância do diálogo como fonte de abertura para a alteridade, considerando que este aspecto emergiu nas falas dos entrevistados. A experiência estética, por sua vez, é apontada no texto como uma possibilidade de ampliação da compreensão da cegueira pela comunidade escolar. A título de exemplo de artefatos estéticos, utilizei ao longo do artigo, poesias, cartuns, trechos de obras literárias, bem como exemplos de vídeos da internet e do cinema.

$\mathrm{Na}$ hermenêutica filosófica de Gadamer, de acordo com Flickinger (2014), existem diversos tipos de diálogo. No denominado diálogo verdadeiro, não pode haver entre os interlocutores desejos pré-determinados, como nos diálogos comerciais, os terapêuticos e os interrogatórios. Neste modelo de diálogo, concebido por Gadamer, os envolvidos não necessitam impor os seus pensamentos ao outro e nem devem selecionar apenas ouvir o que lhes convém, de modo que é preciso que haja uma abertura mútua entre os interlocutores. No diálogo verdadeiro, estes necessitam apresentar a disposição para:

[...] entregar-se a um processo social aberto; o reconhecimento mútuo da autonomia dos parceiros; a capacidade de ouvir um ao outro; sua interdependência no sentido de aceitarem que somente juntos chegarão a um resultado construtivo; e a renúncia a quaisquer verdades últimas (FLICKINGER, 2014, p. 83).

$\mathrm{Na}$ esteira de abertura ao outro por meio do diálogo verdadeiro, Nadja Hermann ressalta que: "A alteridade dá-se pela presença de um outro que nos interpela e força a abrir nosso horizonte interpretativo. Por isso a identidade do interlocutor não está absolutamente fixada, mas se desenvolve na conversação" (HERMANN, 2011, p.144).

Para a autora, outra possibilidade de abertura à alteridade diz respeito à experiência estética.

O termo "estética" é originalmente derivado do grego aisthesis e significa percepção sensível. Baumgartem retomou o termo e o definiu como conhecimento sensível através dos sentidos, da percepção sensível numa reação ao excesso de racionalismo do iluminismo, que associa a verdade apenas ao domínio conceitual (HERMANN, 2017, p.124) 
De acordo com Hermann (2017), a experiência estética se configura como uma possibilidade de abertura à alteridade por meio do universo do sensível. Isto ocorre no sentido de que a experiência estética promove o rompimento com o habitual e convida os sujeitos a novas interpretações e compreensões de situações não vislumbradas pela "tradição racional”, de modo que é possível perceber o outro. A própria escola poderia possibilitar aos alunos um maior contato com a experiência estética, uma vez que:

\begin{abstract}
A ação educativa, sensível à beleza e à liberdade de imaginação que estão presentes nas manifestações artísticas, abre a possibilidade para a alteridade, para o reconhecimento do outro. A justificação para a ação educativa é aqui estética no sentido da profunda satisfação sensorial que provoca, ao mesmo tempo em que forma o espírito, revelando sempre mais o equívoco de uma educação articulada de modo estritamente racional (HERMANN, 2005, p.74).
\end{abstract}

A autora demarca que, através da experiência estética, se abre a possibilidade "para nos tornar sensíveis e receptivos às diferenças e àquilo que consideramos estranho ou sequer reconhecemos, como um modo de abertura à alteridade e, sobretudo, como uma possibilidade educativa na construção de uma nova sensibilidade" (HERMANN, 2017, p.121). Hermann (2017) enfatiza que a experiência estética corresponde àquela que: “[...] acontece pela obra de arte, mas não exclusivamente, pois ela pode ocorrer também em situações cotidianas, assistindo a um jogo, vendo uma tapeçaria, diante de cenas da natureza, ouvindo música, lendo poesia, etc" (HERMANN, 2017, p.125).

A estética promove um contato com situações e realidades distintas daquelas habituais e permite a compreensão do novo por meio dos canais do sentido. Deste modo, de acordo com Hermann, a experiência estética nos possibilita "tornar sensíveis e receptivos às diferenças e aquilo que consideramos estranho ou sequer reconhecemos, como um modo de abertura a alteridade" (HERMANN, 2017, p.123). Neste sentido, promover situações em que se possibilitem experiências desta natureza se revela como um caminho de abertura ao outro, o qual pode ser explorado nos cursos de formação docente, a fim de favorecer o reconhecimento das necessidades básicas da comunidade cega.

No que tange à abertura à alteridade através do diálogo, no caso dos cegos entrevistados, o apoio da família aparece como ponto fundamental para a superação dos obstáculos enfrentados por estes alunos, no que se refere ao ensino e à aprendizagem de Matemática. Por meio do diálogo com familiares e da exposição das necessidades não atendidas pelo sistema de ensino, a entrevistada Luize relata que:

O meu pai acabava fazendo tudo, então, eu só perdia tempo lá (escola especial), eu tinha que fazer tudo em casa mesmo. O meu pai ficou com a função da escola especial mesmo. Meu pai fazia os gráficos com material de sucata: lixa, 
cordão e cola colorida que muitas vezes não secava para levar para aula. Então o meu pai ligava a máquina de lavar louça, que ficava quente após o uso para colocar as folhas em cima para ver se secava mais rápido. Que mão de obra, tá louco!!!! (L. 14)

Pode-se pressupor que o pai de Luize estava aberto às necessidades da alteridade e tomou ciência destas muito provavelmente a partir do diálogo verdadeiro com a filha. Além disso, nestes trechos, verifiquei que essas tarefas extraclasse, desempenhadas pelos alunos cegos com o auxílio dos familiares, manifestam a importância de reconhecer as especificidades de cada deficiência, o que, de acordo com Luize, não foi realizado pela escola especial. Um professor que não conhece essa realidade e não se abre ao diálogo verdadeiro, a fim de escutar o aluno, terá dificuldades de efetivar a inclusão educacional do cego.

Com esse mesmo viés do reconhecimento familiar, apresento o extrato da entrevista do acadêmico Fábio. Neste, percebo que, para ter o material escolar em Braille, ele precisava transcrevê-lo, com o auxílio da mãe e com antecedência, para poder acompanhar as atividades escolares junto a seus colegas de classe.

Muitas vezes, eu recebia o material em tinta, na escola. Em casa, minha mãe ditava tudo para que eu copiasse, em Braille, e a professora de AEE apenas construía os gráficos com suas adaptações. Era muito trabalhoso, mas pelo menos eu podia acompanhar a aula junto com os meus colegas (F. 14).

$\mathrm{Na}$ fala da entrevistada Josi, verifico outra situação em que a alteridade se manifesta como fundamental no processo de desenvolvimento da pessoa cega. Neste excerto, observo que o reconhecimento das dificuldades impostas pela cegueira foi superado a partir do auxílio do professor, dos colegas de classe, de funcionários da escola e da prima.

Nessa época, não havia sala de recursos, eu dependia de colegas ou pessoas da secretaria da escola para me ditarem o material dado em aula. Além disso, eu estudava na mesma sala da minha prima, que anotava tudo e lia para mim. $\mathrm{Na}$ prática, foi bom para as duas, pois, na medida que ela lia e me auxiliava na resolução dos exercícios, ela também aprendia (J.7 e 10).

Além disso, a fala de Josi revela também que a prima igualmente se beneficiava enquanto a ajudava, o que permite inferir que, em geral, quem se dispõe a reconhecer o outro, por meio do diálogo verdadeiro, também se abre à própria mudança. Conforme Hermann (2011), "O diálogo tem, assim, uma força transformadora, pois, quando se realiza efetivamente, algo nos afeta e nos transforma" (p. 144).

Em contrapartida, quando o reconhecimento não acontece, sobretudo na própria família, o aluno cego provavelmente enfrentará mais dificuldade em se adaptar ao 
contexto escolar. De acordo com a entrevistada Luize, muitas famílias creditam apenas à escola a responsabilidade pelo ensino e aprendizagem dos estudantes cegos.

Muitos pais acabam deixando tudo para a escola especial fazer, assim os filhos ficam prejudicados. A família é muito importante para o sucesso da educação do cego, muitas pessoas desistem por falta de apoio familiar (L. 16 e 70).

A instituição regular de ensino e mesmo a especial, porém, não são capazes de suprir todas as necessidades básicas de um estudante cego, pois não dispõem de todos os recursos necessários para o ensino e a aprendizagem destes estudantes, o que pode inclusive gerar evasão. Assim, é importante que a família perceba tal lacuna e busque auxiliar a escola no reconhecimento destes sujeitos.

Em algumas situações, foram narradas vivências em que a pessoa que se abriu à alteridade foi alguém externo à família ou à esfera da escola regular. No caso da entrevistada Josi, foi um professor de música quem se propôs a fazer a diferença no ensino das disciplinas voltadas para a área das exatas, como pode ser verificado no relatado a seguir:

\footnotetext{
Uma coisa que me ajudou muito no aprendizado dos sinais matemáticos em Braille foi que na mesma época comecei a estudar música, em Braille. Muitas simbologias são semelhantes às questões dos compassos musicais, por exemplo, as frações $3 / 4 \mathrm{e} \frac{1}{2}$, isso é Matemática pura. Além disso, o professor de música virau meu professor particular de Química, Física e Matemática. Ele fez uma cartilha em Braille com os sinais mais utilizados (J. 18)
}

A pedagoga Josi relatou, em sua entrevista, que, ao longo de sua trajetória escolar, passou por três estágios: visão normal, baixa visão e cegueira. No momento em que ficou cega, desistiu da escola. Entretanto, sua professora de Matemática teve uma atitude de abertura à alteridade, a qual mudou significativamente a vida de Josi, conforme os extratos:

\begin{abstract}
Em um belo dia, eu estava fazendo compras com a minha mãe nas lojas Pompéia e encontrei a minha professora de Matemática. Ela foi quem me estendeu a mão. Ela me perguntou por que eu tinha desistido da escola. Eu respondi que, com a falta da visão, eu não tinha como aprender Matemática. Ela falou que em Matemática ela dava um jeito e me encorajou a retornar para a escola. Foi o impulso que eu precisava!! O que faz a vontade de um professor? Talvez não tenha aprendido tudo, mas, se não fosse essa atitude da professora, eu não estivesse aqui formada, hoje (J. 9 e 13).
\end{abstract}

Fica evidente, neste excerto, que a disciplina responsável pela desistência escolar foi a Matemática, mesma disciplina cuja professora se mostrou aberta à alteridade. Em seu relato, Josi comentou que a professora de Matemática não possuía experiência alguma com o ensino de cegos, o que não a impediu de escutar as necessidades e dar uma oportunidade à aluna. 
Tal situação permite conjecturar que o encontro que marcou a vida da entrevistada, de alguma forma, também modificou a professora, que se propôs a transcender os próprios limites. Hermann (2014) destaca a importância de, pelo diálogo verdadeiro, desacomodar-se frente aos anseios da alteridade: “o diálogo 'nos põe à prova', provoca a exposição de nossas dúvidas diante daquilo que o outro contrapõe. O outro ajuda, sobretudo, a des-cobrir nossos preconceitos e a romper nossos enclausuramentos" (p.490). Deste modo, é importante considerar na fala da entrevistada que tal abertura à alteridade só aconteceu devido ao processo de inclusão dos alunos cegos na escola regular.

Em outras falas, também é possível notar a abertura para alteridade por parte de outros professores. Luize relata que recebia atendimento de Matemática fora do horário escolar e que professoras, incomodadas com os repetidos atrasos na confecção de materiais em Braille, aprenderam o código para agilizar o processo de confeccionar o material, como pode ser percebido nos extratos a seguir:

Às vezes eu tinha algum horário com as professoras, mas por boa vontade delas. (L. 19)

Até que duas professoras, da escola regular se irritaram com essa situação (de atraso na confecção de materiais adaptados e provas em Braille) e aprenderam Braille. A partir daí, acabavam fazendo as minhas provas para todos outros professores. Elas deram um jeito (L. 33).

Os relatos desta categoria partiram de estudantes que conseguiram driblar a falta de recursos, bem como as limitações impostas pela cegueira, seguindo seus estudos, sobretudo devido à abertura efetivada pelo diálogo verdadeiro de outra pessoa para a alteridade. Desta maneira, a presença do outro foi notada por alguém, ou seja, a pessoa cega foi ouvida e suas necessidades educacionais básicas foram atendidas, fato que possibilitou de certa maneira o desenvolvimento educacional destes alunos. A partir da convivência e do diálogo, as pessoas se abriram à alteridade, bem como se dispuseram a reconhecer as potencialidades do outro, os quais precisavam de adaptações para se desenvolverem. 


\subsection{A "visão" do cego sobre a cegueira}

Figura 3: Cartoon ilustrativo sobre a categoria

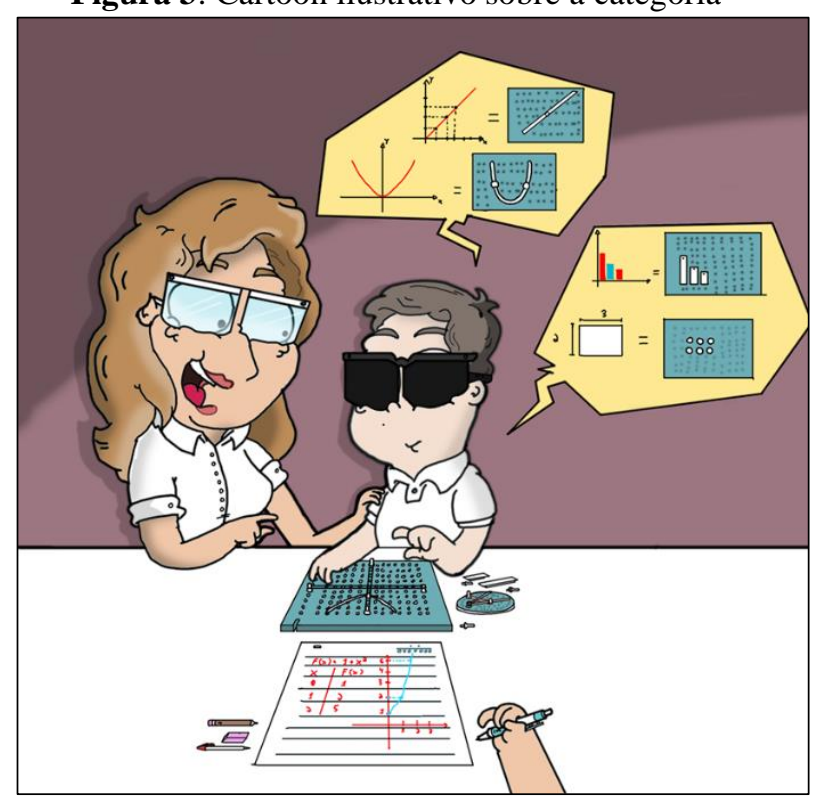

Fonte: Alisson Mendes (egresso do IFRS - campus Rio Grande)

Essa categoria emergiu a partir do agrupamento das unidades relativas às situações descritas como ideais pelos entrevistados no que diz respeito ao ensino e à aprendizagem de Matemática para alunos cegos. Assim, nesta seção, apresentarei as expectativas dos alunos cegos entrevistados em relação ao sistema educacional, tanto na esfera regular, quanto na especial; bem como em relação a seus professores de Matemática e de AEE.

Através da escuta atenta da história de vida de cada participante, foi possível compreender o árduo caminho percorrido pelos estudantes cegos e os ideais destes para um melhor aproveitamento escolar. Este processo de regressão histórica, efetivado por meio da linguagem, permitiu-me ir ao encontro da proposta de Hermann, para quem:

[...] nossa relação com o mundo não parte mais da consciência constituída pelo suprassensível, que se apropria do outro a partir de suas estruturas cognitivas; parte da possibilidade do compreender contida na linguagem e na historicidade. A linguagem é uma forma de vida que permite uma abertura ao outro (HERMANN, 2014, p. 145).

Nesse viés, por meio deste diálogo verdadeiro, conhecer os ideais dos cegos nos aproxima de uma abertura à alteridade. Tal abertura, mais do que oferecer uma perspectiva prescritiva, dispõe da potencialidade de vir a contribuir com ações futuras as quais reflitam e planejem uma escola inclusiva.

Os participantes da pesquisa, em diversas ocasiões, enalteceram a linguagem como meio capaz de superar as dificuldades em relação à inclusão de cegos na escola 
regular. Neste ponto, novamente emerge a importância do diálogo entre professor e aluno, constatação que fica evidente no extrato do acadêmico Fábio:

A coisa mais importante em uma sala de aula é o diálogo entre professor e aluno. Com o diálogo, o aluno se sente seguro e sabe que se alguma coisa der errado ele vai poder contar com o professor (F. 29).

O bom professor precisa acolher o aluno e aprender com o aluno também. O professor vai passar por situações difíceis, mas com o diálogo com o aluno é possível superar (F. 43).

Hermann sinaliza que o verdadeiro diálogo não pode inibir a espontaneidade e deve pressupor uma disposição mútua tanto para falar quanto para ouvir. No âmbito educacional, a filósofa alerta que:

O próprio Gadamer destacou que, muitas vezes a docência revela nossa incapacidade para o diálogo, especialmente quando o professor entende que, para ensinar, ele deve expor o pensamento, revelando assim, a estrutura monológica da ciência que não nos habilita para a conversação. Portanto, a abertura ao outro pelo diálogo é, sobretudo, uma disposição para ouvir e construir um mundo comum (HERMANN, 2014, p. 151).

Neste panorama, é fundamental que o professor procure escutar a história de vida do aluno cego, uma vez que existem diferenças significativas, nas formas de aprendizagem, entre o aluno cego congênito e o aluno com cegueira adquirida. Além disso, na opinião dos entrevistados, é importante que o professor conheça os diferentes recursos pedagógicos destinados ao ensino de Matemática para cegos. Desta maneira, efetiva-se o processo de construção deste mundo comum, processo este que, conforme ressaltam os estudantes cegos, deve partir de uma iniciativa do docente. Tal constatação foi mencionada pelos entrevistados Josi e Marcelo:

Se a escola possuir sala de recursos ele (professor) deve procurar mais informações sobre esse aluno. (J. 37)

É muito mais difícil do aluno cego procurar o professor esse movimento, do diálogo, deve partir do professor, acho que é mais fácil. O dialogar, o conversar e discutir sobre a melhor maneira de agir com determinado aluno. (M. 22)

Além da ênfase no diálogo, a professora Josi destaca um relativo mal-estar dos professores de Matemática ao se depararem com situações distintas, com as quais não estão acostumados. Josi prescreve que:

O professor precisa perguntar, tem que quebrar esse tabu que professor sabe tudo. Principalmente o de Matemática, como ele não sabe? Se não sabe como lidar com o cego precisa perguntar. Tem que falar com o aluno, saber quais os recursos que esse aluno utiliza ou conhece. (J. 36)

Invariavelmente, é possível observar nos excertos a recorrência do diálogo autêntico como o aspecto fundamental para o sucesso da Educação Matemática na escola regular. De acordo com Hermann: 
O diálogo autêntico, aquele em que nos implicamos e do qual não sabemos o que resultará, apresenta a possibilidade de criarmos um mundo comum, decisivo para a ética em educação, pois permite o convívio, o acolhimento e a expansão de nossa própria individualidade (HERMANN, 2014, p. 491).

A partir deste ponto de vista, recorro às palavras da entrevistada Suelen, a qual destaca:

O mais importante para um professor de Matemática atender um aluno cego é a comunicação. Tem que perguntar. Não sei, me explica. Isso é fundamental. Tanto para os professores quanto para gente. (S. 26)

Tem professor que não vêm falar contigo. Imagina? A primeira coisa que você precisa quando encontra o cego é falar. Eu sou muito comunicativa. (S. 27)

Esta abertura dialógica pressupõe também o movimento do professor em direção ao conhecimento das especificidades que envolvem os processos de ensino e aprendizagem de Matemática para cegos, em especial, o código Braille. Tal processo envolve a ciência de que, com o Braille, o cego demora mais para realizar as tarefas propostas e despende de um volume maior de material. Através deste sistema o aluno cego tem acesso a toda a simbologia específica da Matemática, necessária para o progresso educacional. Portanto, conhecer o Braille, além de respeitar as particularidades históricas da comunidade cega, é importante para o sucesso do diálogo entre professores e alunos cegos. Tal afirmação pode ser apreciada nos extratos de Luize e Leidiane:

Um professor diferenciado de Matemática é aquele que sabe Braille, pois vai ter condições de buscar outras informações necessárias para o meu aprendizado. Além disso, ele pode auxiliar os outros professores da escola. $\mathrm{O}$ professor deve saber sobre a dificuldade, em relação ao tempo, para realizarmos algumas tarefas em Braille e claro ter muita paciência. (L. 67) O Braille é muito importante para o aprendizado de Matemática, pois o Braille é mais concreto. $\mathrm{O}$ aluno pode perceber através do tato (Le. 25).

Para favorecer o conhecimento e a disseminação do código Braille em contextos de formação de professores, recorro à experiência estética como possibilidade. Vídeos disponíveis na internet, filmes ou documentários sobre a invenção de Louis Braille ${ }^{9}$ ou até mesmo uma poesia representam artefatos estéticos capazes de sensibilizar os professores no reconhecimento das necessidades da alteridade. Apresento, neste momento, o soneto do professor cego Waldin de Lima, para exemplificar esta possibilidade:

\section{SONETO A LOUIS BRAILLE}

Aquele Menino genial, inquieto, dos cegos transmudou a própria Vida quando em sua Alma a glória foi concebida na grandeza de um tátil alfabeto!

\footnotetext{
${ }^{9}$ Por exemplo, o vídeo disponível em: https://www.youtube.com/watch?v= DpkGBJHG4A, o qual relata a invenção do código Braille.
} 
Louis Braille, Pedagogo ou Arquiteto, se teve um dia sua visão perdida buscou em sua Alma brava e destemida seu tesouro real e predileto.

Sistema de pontos bem ordenados representam os sinais convencionados: outra forma de ler e escrever

Sistema novo de escrita e leitura tirou os cegos da vida obscura que levaram à margem do Saber

Conhecer a especificidade de cada indivíduo é uma tarefa árdua, a qual exige muita disponibilidade do professor em se abrir à diferença, demandas estas que, em um país como o Brasil, em que muitas vezes a jornada de um professor da Educação Básica é tripla, ficam difíceis de cumprir. Ainda assim, é importante, dentro do possível, que o professor busque sair da zona de conforto do que é familiar e se abra ao estranho, pois,

[...] o estranho, na medida em que nos tira do habitual e do familiar, cria as condições para quebrar a unidade inquestionável que nos é dada pelo pertencimento a uma tradição (familiaridade). Se a tradição tem um papel significativo no fenômeno da compreensão, na medida em que contém a historicidade que nos constitui e que é coextensiva à vida que vivemos; a estranheza, por sua vez, atua como distanciamento temporal, gerando a tensão produtiva com a qual se estabelece a própria situação hermenêutica (HERMANN, 2011, p.143).

Os alunos entrevistados, em suas falas, recomendaram sobre a postura ideal dos professores de Matemática frente à inclusão de alunos cegos na escola regular. Algumas destas, podem ser apreciadas nos extratos a seguir:

Quando o professor recebe o aluno cego começam os questionamentos: e agora como que eu faço? Como vou adaptar? E o mesmo caso que eu falei do aluno, se ele não receber a preparação para entrar na escola regular sua adaptação será prejudicada. As duas partes precisam ter os mesmos objetivos o aluno deve se adaptar a escola regular e o professor se adaptar ao aluno. (F. 20)

O professor precisa mostrar de forma concreta para o cego, não é tão difícil, basta entender que é diferente. Não é só desenhar no quadro, tem que levar o material concreto (Le. 24).

Outro aspecto fundamental apontado nas entrevistas para o sucesso da educação de alunos cegos na escola regular é o AEE, oferecido na própria escola, quando esta possui uma sala de recursos multifuncionais, ou na escola especializada, quando não houver esta sala.

Muitas vezes, eu e a professora de AEE tivemos que quebrar a cabeça para adaptar o material, pois os professores da escola regular e os da especial não sabiam como fazer (F. 18). 
Em outras ocasiões, mesmo quando há sala de recursos, o aluno cego frequenta a escola especializada para diferentes atividades como: receber auxílio em atividades de Orientação e Mobilidade (OM), realizar práticas desportivas, participar de cursos, receber atendimento psicológico e pedagógico, participar de grupos de teatro, de música e artesanato. Em função disso, a ligação do aluno cego com a escola especial, no caso do Rio Grande com a Escola Especial José Alvares de Azevedo, é muito intensa. Por esse motivo, os participantes da pesquisa mencionaram que gostariam de receber um maior apoio da instituição, como pode ser percebido no relato de Fábio:

[...] ela (a escola especial) precisa instrumentalizar o aluno com os recursos disponíveis para que a Matemática não vire um problema na escola regular. A escola especial precisa dar mais suporte aos alunos (F. 16).

Além do mais, os entrevistados acreditam que os professores da escola regular devem receber da escola especial orientação e capacitação para trabalhar com os cegos.

Uma coisa que eu condeno é que os professores, da escola regular deveriam receber um curso básico de como trabalhar com cegos. Esse curso deveria ser fornecido na escola especial. (F. 19)

Além disso, eu imagino o desespero de alguém formado que recebe um aluno que ele não sabe como agir. O que fazer? Onde buscar ajuda? Então a escola José Alvares deve dar esse suporte. Nós precisamos de pessoas com qualificação em Matemática para ajudar as pessoas que ficaram cegas e os alunos que estão em um nível mais adiantado de ensino (M. 26).

Entretanto, a carência de profissionais na área específica de Matemática para ministrarem estes cursos, a falta de disponibilidade dos professores da escola regular em procurar se especializar, bem como dos docentes da escola regular em buscar se atualizar entravam a realização destas ofertas, como pode ser percebido nos extratos a seguir:

Acho que falta atualização dos professores de sala de recursos e até mesmo da escola especial, para poder ajudar os professores de Matemática da escola regular. (S. 31)

Eu acho muita falta de interesse dos professores da escola especializada não conhecerem todos os recursos disponíveis para nós, eles têm contato com cegos de outros lugares. A escola especial tem que saber (L. 45).

Outra constatação muito recorrente nas histórias contadas pelos entrevistados foi das atividades realizadas nas aulas de AEE serem similares às desenvolvidas em sala de aula. Tal situação, na opinião de Luize, enfatiza na incapacidade do aluno cego, sem criar uma solução, conforme pode ser percebido a seguir:

O AEE deve ser realizado de maneira diferente ao que é visto em sala de aula, pois se o cego não está aprendendo não é fazendo a mesma coisa que ele vai aprender. Aquele método está complicado para ela, então que se faça um jogo, uma brincadeira ou outro recurso. Fazer a mesma coisa que na sala de aula só reforça a ideia que o cego não é capaz de aprender (L. 64). 
A pedagoga Josi ponderou que o professor, quando recebe um aluno com cegueira, necessita estudar, se preparar para melhor atendê-lo. Segundo ela, tal situação integra o cotidiano da profissão docente, como pode ser percebido a seguir:

\begin{abstract}
No momento que a pessoa escolhe fazer licenciatura, ela deve saber que todos são diferentes e que existem pessoas com deficiência. Então ele (professor) precisa estar preparado, não é obrigado a saber tudo, mas precisa buscar esse conhecimento quando não souber. (J. 46)

Quando o professor não sabe o seu conteúdo, ele não estuda para preparar sua aula? Então, quando tem uma deficiência que ele não domine também é preciso estudar! Não pode ficar indiferente ao diferente! (J. 40)
\end{abstract}

Uma situação que me chamou atenção, na fala dos entrevistados, foi a supressão de alguns conteúdos de Matemática por parte dos professores, especialmente, relacionados à geometria e às representações gráficas, como se observa na fala de Leidiane "eu não estudei geometria por que a professora disse que cego não precisa aprender geometria" (Le. 30). Entretanto, a posição dos alunos foi bem clara quanto a essa opinião a respeito da necessidade de aprendizagem, como pode ser percebida no extrato de Luize: "Não precisamos de facilidades para fazer as coisas, mas sim de adaptação. Eu preciso aprender igual” (L. 74).

Neste sentido, a presente categoria demarcou a situação escolar idealizada pelos alunos cegos entrevistados. Tal perspectiva deve ser considerada nos processos de formação docente, a fim de consolidar a articulação entre a perspectiva teórica e a realidade prática vivenciada na escola.

\title{
5.3 A cegueira de quem não enxerga a alteridade
}

Figura 4: Cartoon ilustrativo sobre a categoria

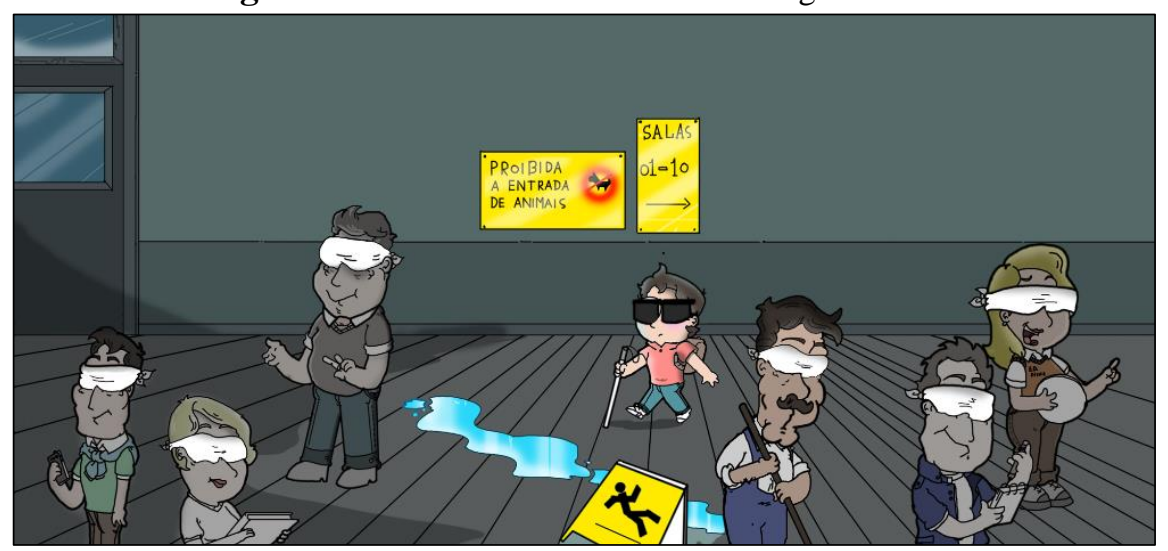

Fonte: Alisson Mendes (egresso do IFRS - campus Rio Grande)

A terceira categoria desta análise revelou o descaso do sistema de ensino com as questões que circundam o cotidiano escolar dos alunos cegos. Ilustra-se no texto por meio 
da metáfora utilizada no título da seção, pois, ao não perceber escancarados problemas que os alunos cegos enfrentam em sua escolarização, estamos todos cegos, parafraseando o autor português e prêmio Nobel de Literatura José Saramago ${ }^{10}$, autor do livro Ensaio sobre a cegueira, no qual aponta para uma cegueira da razão que acometeu a civilização contemporânea: "Penso que não cegámos, penso que estamos cegos, Cegos que vêem, Cegos que, vendo, não vêem” (SARAMAGO, 1995, p. 310).

Tal cegueira se manifestou, conforme explicitado anteriormente, também na ausência de um número preciso com relação à quantidade de cegos na cidade do Rio Grande. A própria Associação de Cegos, da cidade do Rio Grande, não dispõe deste dado, segundo afirma o Presidente e participante da pesquisa Marcelo: "não sabemos quantos cegos somos na cidade" (M. 1). Tal inexistência consiste em uma dificuldade de propor ações precisas que beneficiariam a população cega.

Além disso, nas entrevistas realizadas, notei que os problemas dos cegos com a Matemática iniciaram nas primeiras séries da Educação Básica, sendo que a dificuldade relatada em fazer cálculos numéricos perpassou os dizeres dos participantes da pesquisa durante toda a referida etapa da escolarização.

A pessoa normovisual, habitualmente, aprende os algoritmos das operações básicas com o auxílio do lápis e do papel. A pessoa cega, por sua vez, não possui essa possibilidade, pois, com a escrita em Braille, tal prática torna-se inviável. Neste caso, as ferramentas habituais são substituídas pelo Sorobã, que é um instrumento bastante similar ao ábaco, o qual permite ao cego realizar cálculos numéricos de maneira distinta da utilizada em tinta. Contudo, esta introdução à Matemática para os cegos entrevistados foi um tanto prejudicada, em função do despreparo dos agentes educacionais no que se refere ao manejo da referida ferramenta, como pode ser percebido nos extratos da pedagoga Luize:

\begin{abstract}
Eu comecei a aprender Matemática no Sorobã, mas eu nunca tive aulas para aprender o Sorobã, era na guerra. (L. 4)

Nessa época, não tinha sala de AEE, então eu ia para escola especializada na parte da manhã. Eu ia para escola especializada para aprender a usar o Sorobã, mas as professoras também não sabiam usar direito. Eu lembro que elas passavam fazendo cursos para aprender mexer no Sorobã. Na escola regular ninguém sabia usar o Sorobã, só eu, que também não sabia (L. 10).
\end{abstract}

Este problema com os cálculos matemáticos acarretou uma iminente reprovação de Luize no terceiro ano e tal fato desencadeou a decisão de "que a partir desse momento iria fazer os cálculos de cabeça, uma vez que eu não conseguia trabalhar com o Sorobã

\footnotetext{
${ }^{10}$ Entrevista disponível em: http://www1.folha.uol.com.br/fsp/1995/10/18/ilustrada/1.html
} 
(L. 7)". A aluna, ainda muito cedo, abandonou um recurso fundamental para a aprendizagem da Matemática, pois tanto a escola especial quanto a regular não disponibilizaram condições favoráveis para seu aprendizado.

Além do mais, conforme a pesquisadora Riffel (2015, p. 61) argumenta, culturalmente, "a Matemática é uma atividade que se realiza por escrito". Portanto, o cego, ao decidir realizar os cálculos "de cabeça", distancia-se das normas impostas e valorizadas pela escola, as quais representam o universal formal. Fica evidente, neste cenário, o descaso do sistema de ensino com a alteridade que escapa a este padrão, no sentido de que não há a previsão, em nenhuma etapa da formação inicial dos professores, de um preparo para o uso desta ferramenta tão necessária para a aprendizagem dos cegos. Tal ausência foi verificada no Projeto Político Pedagógico ${ }^{11}$ do Curso de Licenciatura em Matemática da FURG, o qual não contempla, em sua grade curricular obrigatória, disciplinas que atendam a educação de aprendizes cegos.

Outro fato recorrente nas falas dos alunos cegos da cidade do Rio Grande consiste na dificuldade em utilizar o Código ${ }^{12}$ Matemático Unificado para Língua Portuguesa, em Braille. O referido código corresponde à representação das mais diversas simbologias Matemáticas por meio do sistema Braille. Como esta escrita é linear, não existe a possibilidade de escrita sobrescrita ou subscrita motivo pelo qual existe tal código. Entretanto, os alunos consultados relataram o desconhecimento deste por parte do sistema escolar, tanto na escola regular, quanto na especial. A fala expressa essa dificuldade.

Outro problema eram os sinais de Matemática. Eu não sabia, por exemplo, aquele pertence e não pertence. Eu escrevia por extenso: pertence, não pertence, está contido.... então eu resolvi inventar os sinais, até por que ninguém sabia (L. 28).

Tal ausência de conhecimento do código foi superada na escola mediante a criação de alternativas paliativas pelos próprios estudantes. Porém, o aluno cego ficou prejudicado no momento da realização de um concurso em que as provas eram exclusivamente em Braille, como, por exemplo, no vestibular. Luize relatou tal dificuldade no excerto: "No vestibular, eu não conhecia muitos sinais (matemáticos), pois eu sempre tive quem lesse a prova. No vestibular eu não tive isso (L. 68)". Aqui, mais

\footnotetext{
${ }^{11}$ Disponível em: http://www.imef.furg.br/images/stories/documentos/projeto pedaggico matemtica Licenciatura.pdf

${ }_{12}$ Brasil. Ministério da Educação. Secretaria de Educação Especial. Código Matemático Unificado para Língua Portuguesa. Elaboração: CERQUEIRA, Jonir Bechara et al. Brasília, 2006.
} 
uma vez, percebo a cegueira do sistema educacional, o qual não percebe que o aluno passa toda a Educação Básica sem conhecer os sinais básicos da disciplina de Matemática.

Ademais, a falta de profissionais com formação em Matemática na escola especial para prestar auxílio aos professores das salas de AEE corrobora para que esse problema permaneça até os dias atuais. Esta carência ficou evidente na fala de Marcelo, que afirma: "Nós precisamos de pessoas com qualificação em Matemática para ajudar as pessoas que ficaram cegas e os alunos que estão em um nível mais adiantado de ensino" (M. 25). Tal situação também foi apontada como recorrente pela pesquisa de Dias (2012), relativa ao ensino de Matemática para alunos cegos, em Portugal, pois:

[...] apesar de serem submetidas às mesmas experiências de aprendizagem dos seus pares, não existem garantias de que o professor de Matemática conheça a grafia Matemática Braille. A não existência de orientações metodológicas para o ensino dos conteúdos de Matemática com recurso à grafia Matemática Braille e aos sistemas de compensação tátil e auditivo podem comprometer o ensino destas crianças (DIAS, 2012, p. 43).

Outro fator importante para que o estudante cego acompanhe as aulas de Matemática é o recebimento do material didático em Braille. No entanto, o atraso na confecção deste foi um ponto de bastante reclamação por parte dos alunos entrevistados. Este fato pode ser evidenciado nos extratos de Leidiane e Suelen.

Alguns materiais didáticos eram enviados para a Escola Especial e quando chegavam, na escola regular, eu já tinha passado pelo conteúdo, assim acabava nem utilizando esse material. (Le. 16)

Não adiantava enviar o material para a Escola Especial, pois eu ficava sempre atrasada. Eu fazia mais rápido com a máquina Braille do que a escola especial com uma impressora. (S. 15)

Ao aluno cego não foram disponibilizadas as mesmas condições de aprendizagem, de modo que cabe a este, novamente, a criação de soluções alternativas para resolver mais este problema não visualizado pelo sistema escolar. Desta maneira os alunos cegos, muitas vezes, produziam o seu próprio material com o auxílio de um familiar, em uma tentativa de enxergar esta alteridade que não foi vista pelo sistema, como explicitado na primeira categoria deste ensaio.

Ainda no que tange ao material didático disponível em Braille, o assunto relativo ao livro didático também foi bastante recorrente. Isso porque os alunos entrevistados mencionaram que não recebiam o de Matemática utilizado pelo restante da turma. Tal fato prejudica sensivelmente, tanto o acompanhamento durante as atividades de aula, quanto as tarefas escolares domiciliares. Esta situação é percebida nos relatos de Leidiane e Suelen: 
Em relação aos livros didáticos eu nunca recebi. Todo mundo recebe o livro, né? O cego muitas vezes não. Para o professor também é difícil planejar exatamente o que será ministrado em todas as aulas. (Le. 28)

Em relação aos livros didáticos, eu nunca recebi, copiava o que a professora passava no quadro. Os meus colegas tinham o livro eu não. Para estudar eu fazia novamente os exercícios dados em aula (S. 30).

Mesmo que haja legislação ${ }^{13}$ (Lei 10.753/03) que regulamenta a distribuição de livros acessíveis a todos os alunos, a realidade escolar ainda não se adequou à referida lei. Tal constatação também foi comprovada na pesquisa realizada por Riffel (2015), que concluiu que:

Na prática a lei ainda não está sendo obedecida integralmente e muitos livros ou simplesmente não são fornecidos em formato digital ou o são sem as adaptações para a descrição das representações gráficas. Isto limita sobremaneira seu uso, já que durante a leitura do texto pelo programa, a fala é silenciada quando há uma figura, foto, gráfico ou fórmula, o que em livros científicos, por exemplo, ocorre regularmente (RIFFEL, 2015, p. 68).

Uma solução encontrada por algumas escolas para essa situação, apesar de muito trabalhosa, foi a confecção do livro em Braille, através da digitalização com o auxílio de um computador e confecção das figuras artesanalmente, na Escola Especial ou na sala de AEE, o que revela uma tentativa de enxergar esta alteridade. No entanto, quando essa alternativa foi solicitada pelos professores de alunos cegos, ocorreu outra vez um atraso, conforme mencionado por Luize:

Quando a professora pedia uma parte do livro para fazer em Braille, a parte do primeiro bimestre chegava no terceiro. Não adiantava mais nada, eram folhas jogadas fora e trabalho perdido. Desta maneira, decidimos não pedir mais para Escola Especial transcrever o material (L.13).

Mais uma vez, o sistema educacional não percebeu que uma parcela dos alunos não dispunha, no momento necessário, de um dos requisitos básicos que auxiliam o professor e o aluno para uma boa aprendizagem, o livro didático, o que evidencia novamente a cegueira deste sistema em relação aos cegos. Atualmente, essa realidade é um pouco diferente com os livros no formato digital ${ }^{14}$, entretanto, tais livros, muitas vezes, não correspondem às edições impressas recebidas pelos colegas normovisuais, como pode ser notado no extrato:

Naquela época não havia a facilidade do computador, pois hoje os alunos cegos recebem o livro digital, muitas vezes em uma edição antiga, por exemplo: a

\footnotetext{
13 BRASIL. Minuta do Decreto de Regulamentação da Lei do Livro, Lei ${ }^{\circ} 10.753$, de 31 de outubro de 2003. Regulamenta a lei que institui a Política Nacional do Livro. Disponível em: www.livroacessivel.org/o-texto-do-acordo-historico.php\#conteudo. Acessado em: 15/10/2017

${ }^{14} \mathrm{O}$ Ministério da Educação lançou o projeto Mecdaisy, que permitirá a produção de livros em formato digital acessível, no padrão Daisy.o Mecdaisy possibilita a geração de livros digitais falados e sua reprodução em áudio, gravado ou sintetizado. Informações disponíveis em: http://intervox.nce.ufrj.br/mecdaisy/
} 
turma usa o livro na edição de 2017 e o cego de 2014, mas já é melhor do que não ter nada. As editoras ainda não estão acompanhando isso (Le. 17).

Outra reclamação bastante recorrente na fala dos entrevistados esteve relacionada à aprendizagem de Matemática desprovida de significado, ou seja, a disciplina era decorada para passar nas avaliações. A entrevistada Luize relatou que: "aprendia muita coisa decorando. Não entendia o porquê das coisas, por exemplo, aprendia a tabuada 3x6 é 18 , mas $6 \times 3$ era só depois na hora da tabuada do 6." (L. 4)

A referida ausência de significado para a aprendizagem se manifestou também em duas situações relativas ao ensino de geometria e das representações gráficas, nas quais os entrevistados declaram ter decorado o conteúdo. Alguns relataram não terem recebido material adaptado, enquanto outros o recebiam totalmente pronto. Esta última ocorrência impossibilita uma aprendizagem completa, pois não permite a construção gráfica por parte do estudante. Tal constatação pode ser notada nos extratos de Fábio e Luize:

\footnotetext{
A geometria era muito difícil por que a professora de AEE não sabia o conteúdo e muitas vezes a adaptação não existia, era zero, dessa maneira não tinham como me cobrar na prova, então decorei algumas coisas para responder nas provas. (F. 23)

É muito mais fácil tu ganhares o gráfico pronto e decorar ele para responder as perguntas. É muito mais difícil fazer o gráfico. Geometria? O que é isso? Eu não lembro mais nada. Não haviam provas adaptadas (L. 71).
}

A principal consequência deste cenário de invisibilidade do aluno cego é uma lacuna na aprendizagem da Matemática. Estes estudantes, via de regra, decoraram os conteúdos para as avaliações, mas não efetivam a aprendizagem. Duas entrevistadas, as quais hoje são professoras na Educação Infantil, relataram que, no passado, não aprenderam e não percebiam, enquanto alunas, sentido na Matemática, o que, consequentemente, comprometeu o ensino posterior da disciplina, como professoras, de acordo com o que pode ser apreciado nos extratos:

$\mathrm{Na}$ faculdade de pedagogia, eu não precisei da Matemática. Eu fiz apenas uma disciplina para te ensinar a ensinar Matemática, mas como eu não aprendi como vou ensinar? Então eu não me atrevo a ensinar Matemática. (L. 59)

Eu me acomodei, pois pensava que nunca mais iria utilizar Matemática: "Pra que saber fórmula de Bháskara?", "Pra que saber a raiz de 2,16?", mal podia imaginar que isso me faz falta, hoje, para trabalhar com as crianças (J. 26).

Assim como tais entrevistadas perceberam tardiamente a relevância desta aprendizagem, um dos entrevistados também reconhece a importância da Matemática apesar de todas as dificuldades enfrentadas no estudo da disciplina: "A Matemática te abre um mundo novo de possibilidades, pois contar e fazer cálculos faz parte do cotidiano" (M. 43). Isto evidenciou que, muitas vezes, o estudante cego quer aprender, mas acaba desistindo por inaptidão do sistema em enxergá-lo. 
Em função deste cenário de invisibilidade do estudante cego, argumento que o ensino de Matemática, tanto na escola regular quanto no AEE, bem como na escola especializada, necessita de uma reformulação. Além da presença de profissionais capacitados para o ensino de Matemática especificamente para alunos cegos, é necessário que haja uma interlocução entre estas esferas: a escola regular, o AEE e a escola especializada, para que, juntos, possam enxergar as necessidades dessa alteridade.

Assim, em um futuro próximo, os cegos do Rio Grande não chegarão à conclusão semelhante a da pedagoga Luize: "Uma pergunta interessante seria quantos cegos foram para a área da Matemática no ensino superior? Quase ninguém, por que não aprendemos Matemática, na Educação Básica” (L. 51).

\section{Considerações finais}

Verifiquei, por meio do presente estudo, que a imprecisão relativa à aferição do número de alunos cegos e da especificação do grau de deficiência visual, tanto dos estudantes da universidade quanto da cidade, influenciou diretamente na disponibilização dos recursos pedagógicos bem como na delimitação de estratégias de capacitação docente.

Outro aspecto constatado através desta pesquisa referiu-se ao fato de que, apesar da demora histórica para que os cegos ingressassem no ensino superior, a partir de 2010, o acesso destes alunos a esse grau de escolarização aumenta paulatinamente, na cidade do Rio Grande. Ainda assim, os alunos revelaram que se sentem em defasagem em relação à Matemática, fato o qual direcionou a opção para um curso superior distante desta disciplina.

De acordo com a primeira categoria, Alguém notou a presença do outro, foi possível perceber a importância do diálogo verdadeiro, proposto por Gadamer, para uma efetiva abertura à alteridade, a qual corresponde aos alunos cegos em relação ao universal formal, que se refere aos normovisuais. Nas histórias de sucesso escolar, contadas pelos entrevistados desta pesquisa, houve, além de atitudes de superação das dificuldades enfrentadas, a disponibilidade de pessoas, no âmbito familiar e escolar, que se sensibilizaram ao reconhecimento do aluno cego. Estas ouviram as necessidades dos cegos e se propuseram a ajudar, abrindo-se à alteridade.

Neste sentido, a Escola Especial, a qual dispõe de profissionais da área da Psicologia, pode vir a oferecer suporte também às famílias dos alunos cegos, para 
compreender melhor a deficiência e descobrir as maneiras de auxiliar no desenvolvimento das potencialidades dos aprendizes com cegueira. Esse é um processo de sensibilização e de atitude frente à deficiência, o qual deve ser reforçado e compartilhado sistematicamente.

A carência de formação em Matemática por parte dos professores da escola especial relatada pelos entrevistados poderia ser amenizada com a presença de um profissional da área lotado na referida escola - trabalho este que desenvolvi durante minha atuação como professor do quadro municipal. Tal docente seria responsável por centralizar o auxílio às profissionais de AEE e aos professores de Matemática da rede municipal.

No que diz respeito ao tema da inclusão, notadamente, nas últimas décadas, foram inúmeras as políticas públicas com este viés, sobretudo a partir da Declaração de Salamanca. Entretanto, a matrícula de alunos cegos na rede regular não é garantia de que as necessidades educacionais básicas destes sejam contempladas. Mesmo que ainda haja muitas demandas a serem supridas no que tange às especificidades de recursos para atender aos estudantes cegos, a inclusão em si já dispõe do potencial de tornar a escola um ambiente mais colaborativo, em detrimento do individualismo e de um ambiente de competição, valores vigentes na sociedade atual. Isto porque as adaptações realizadas para o ensino de Matemática para alunos cegos podem auxiliar todos os estudantes da classe.

A inclusão dos alunos cegos na Educação Básica é bem mais expressiva se comparada com os níveis mais elevados de ensino. Conforme é possível perceber a partir deste ensaio, esta foi a primeira geração de cegos que chegou ao terceiro grau na cidade do Rio Grande. Para que esta realidade se altere e nos sensibilizemos diante das necessidades do cego de modo que este possa acessar o Ensino Superior, como sociedade, precisamos nos abrir para reconhecer esta alteridade.

A segunda categoria deste ensaio, A visão do cego sobre a cegueira, retrata a observação dos alunos cegos em relação a situações que eles consideram ideias no que tange aos processos de ensino e aprendizagem de Matemática na Escola Regular e ao apoio oferecido pela Escola Especial. Mais uma vez, o diálogo verdadeiro entre professor e aluno foi mencionado como elemento fundamental para o sucesso escolar de aprendizes cegos.

Os entrevistados sinalizaram que o professor de Matemática necessita estar atento ao histórico escolar de cada aluno cego, pois, ao conhecer a história individual, o docente 
terá indícios de como agir e quais os melhores recursos a utilizar. Ao receber um estudante cego, de acordo com os participantes da pesquisa, o professor necessita buscar informações sobre a deficiência visual, sobretudo do sistema de escrita Braille e suas particularidades para o ensino de Matemática. Deste modo, a comunicação entre professor e aluno ocorrerá de uma melhor maneira e evitará situações de conflito de interpretações. Cabe aqui mencionar, que tal tarefa é bastante complexa, especialmente, em se tratando da realidade do professor brasileiro o qual, muitas vezes necessita cumprir uma jornada de trabalho próxima a 60 horas por semana.

Para isso, os processos de formação docente necessitam estar em consonância com a prática encontrada na sala de aula. Nestes processos formativos, não basta o professor se debruçar sobre os referenciais teóricos, é preciso vivenciar a inclusão em sua práxis. Isso poderia ocorrer por meio de parcerias entre as instituições formadoras e as escolas em que há alunos incluídos.

Em relação à Escola Especial, os alunos entrevistados almejam receber maior apoio na disciplina de Matemática, especialmente em relação aos anos finais da Educação Básica e no Ensino Médio. Outra situação destacada pelos entrevistados foi a necessidade de ensinar a simbologia Matemática em Braille, para estudantes com cegueira adquirida. Para amenizar essa situação, existe a necessidade do oferecimento de AEE com profissionais habilitados em Matemática.

Para finalizar, a terceira categoria, A cegueira de quem não enxerga a alteridade, abordou a cegueira do sistema educacional com relação a aspectos fundamentais para o sucesso escolar dos estudantes cegos. A dificuldade em realizar cálculos numéricos foi recorrente nas entrevistas, sobretudo porque os alunos entrevistados revelaram o desconhecimento em relação à utilização do Sorobã. Tal situação não foi visualizada pelo sistema escolar, o que acarretou significativos problemas aos alunos cegos. Esse desconhecimento evidencia, uma vez mais, a desvalorização da cultura cega e a imposição do modo tradicional de ensino.

O desconhecimento da simbologia Matemática em Braille também chamou minha atenção. Este fato, além de dificultar a comunicação entre professor e aluno, gera uma situação desfavorável ao estudante cego, sobretudo quando da realização de provas oficiais, como o vestibular, o Exame Nacional do Ensino Médio (ENEM) e outros concursos. Além disso, esse desconhecimento em relação ao referido código dificulta a autonomia do estudante cego, uma vez que restringe suas possibilidades de entendimento ao se depararem com estes sinais. 
Outra dificuldade não visualizada pelo sistema diz respeito à carência no oferecimento do livro didático adaptado, pois, apesar da legislação vigente garantir que todos tenham acesso, na prática, tal distribuição nem sempre acontece. Esse fato gera um desconforto na relação entre professor e aluno e, mais uma vez, o cego é prejudicado pelo sistema escolar. Soma-se a isso o fato da escassez de materiais táteis para o ensino de gráficos e dos conteúdos relacionados à geometria, criando lacunas significativas no aprendizado destes estudantes.

Para promover a necessária abertura à alteridade, em direção às necessidades do estudante cego, sinalizo para a introdução da experiência estética, nos cursos de formação em Matemática. Tal prática possui a potência de, por meio dos canais da sensibilidade, ajudar os futuros docentes na tarefa de abertura à alteridade. Deste modo, é possível que um número maior de estudantes cegos tenha suas necessidades de aprendizagem atendidas em relação à disciplina na Educação Básica e, consequentemente, condições mais favoráveis para o acesso aos níveis superiores.

Neste contexto, parece-me pertinente que a experiência estética se apresente como um caminho para esta abertura em uma alternativa à primazia da razão a qual impera nas diretrizes que regem os cursos de Licenciatura em Matemática. Nestas, o foco do conteúdo da disciplina restringe-se a fórmulas e conceitos matemáticos. Acredito que se o componente estético for incluído nos Projetos Políticos Pedagógicos dos referidos cursos no Brasil, os professores em formação teriam a possibilidade de compreender que a dimensão racional do conhecimento é importante, mas não suficiente para lidar com a complexidade humana, representada na diversidade presente na escola.

\section{Referências}

BRASIL. Cartilha do censo. Pessoas com deficiência. Luiza Maria Borges Oliveira/Secretaria de Direitos Humanos da Presidência da República (SDH/PR)/Secretaria Nacional de Promoção dos Direitos da Pessoa com Deficiência (SNPD)/Coordenação-Geral do Sistema de Informações sobre a Pessoa com Deficiência, Brasília, 2010.

CLANDININ, D. J.; CONNELLY, F. M. Pesquisa narrativa: experiência e história em pesquisa qualitativa. Uberlândia, Brasil, 2011.

CONDE, A. J. M. Definição de cegueira e baixa visão. Rio de Janeiro: Editora IBC, 2016. Disponível em: http://www.ibc.gov.br/images/conteudo/AREAS ESPECIAIS/CEGUEIRA E BAIXAVISAO/ ARTIGOS/Def-de-cegueira-e-baixa-viso.pdf. Acesso em: 22 ago. 2017. 
DIAS, C. A. da C. B. Jogos matemáticos adaptados à baixa visão e cegueira. 2012. Tese (Doutorado em Estudos da Criança Especialidade em Matemática Elementar) - Instituto de Educação, Universidade do Minho, Braga, 2012.

FLICKINGER, Hans-Georg. Gadamer \& a Educação. Autêntica, 2014.

HERMANN, N. Ética e estética: a relação quase esquecida. EDIPUCRS, 2005.

HERMANN, N. Breve investigação genealógica sobre o outro. Educação \& Sociedade, Campinas, v. 32, n. 114, p. 137 - 149, jan./mar. 2011.

HERMANN, N. A questão do outro e o diálogo. Revista Brasileira de Educação, Rio de Janeiro, v. 19, n. 57, p. 477 - 493, abr./jun. 2014.

HERMANN, N. Ética \& educação: outra sensibilidade. Autêntica, 2017.

HERMANN, N. Ética, estética e alteridade. In: Org. TREVISAN, A.; TOMAZETTI, E. (org). Cultura e alteridade: confluências. Ijuí: Unijuí, 2006. p. 1-12.

INSTITUTO NACIONAL DE ESTUDOS E PESQUISAS EDUCACIONAIS ANÍSIO TEIXEIRA. Sinopse Estatística da Educação Superior 2015. Brasília: Inep, 2016. Disponível em: http://portal.inep.gov.br/web/guest/sinopses-estatisticas-da-educacao-superior . Acesso em: 21 out. 2017.

LIMA, W. de. Canção das Flores. Porto Alegre: Martins Livreiro editor. 2009.

MORAES, R.; GALIAZZI, M. do C. Análise Textual Discursiva. 2. ed. Ijuí: Ed. Unijuí, 2013.

RIFFEL, B. Y. F. Enxergando no escuro: Saberes e práticas sociais de sujeitos com deficiência visual. 2015. Tese (Doutorado em Educação) - Instituto de Educação, Universidade de São Francisco, São Paulo, 2015.

SARAMAGO, J. Ensaio sobre a cegueira. 74. ed. São Paulo: Editora Companhia das Letras, 1995.

Recebido em: 21 de outubro de 2020.

Aceito em: 12 de novembro de 2020. 